\title{
Application of dry-ice blasting for barrels treatment
}

\author{
Antonella Costantini ${ }^{1}$, Enrico Vaudano ${ }^{1}$, Maria Carla Cravero $^{1}$, Maurizio Petrozziello ${ }^{1}$, Attilio Bernasconi ${ }^{2}$, and Emilia \\ Garcia-Moruno ${ }^{1, a}$ \\ ${ }^{1}$ Consiglio per la ricerca in agricoltura e l'analisi dell'economia agraria (CRA), Centro di ricerca per l'Enologia, \\ via P. Micca 35, 14100 Asti, Italy \\ ${ }^{2}$ Mec srl, viale Italia 19, 28010 Caltignaga (NO), Italy
}

\begin{abstract}
The main aim of this work was to test a dry-ice basting method to regenerate the barriques in order to prolong their life. In addition, this treatment for barrels can also represent an alternative to the use of sulfur dioxide for the barrique sanitization, in line with the guidelines of oenological practices for sustainable development proposed by the OIV (International Organization of Vine and Wine) (sustainable development, food security: reduction the content of sulfites in wine). The effect of the blasting with dry ice for the treatment of barrique has been studied from a microbiological and sensory point of view. Microbiological analyses were carried out using wine contaminated with Brettanomyces and Lactobacillus; results showed a reduction of contaminant of 98-100\%. Finally, it was evaluated the impact of this treatment on the sensory profile of wine. In this regard the wine aged in a barrique dry-ice blasted was compared with a wine aged in a barrique treated with sulfur dioxide. From the sensory analysis emerged that the dry-ice blasting treatment can regenerate the barriques, this confers to the wine increased notes of vanilla and boisé. The benefits that derive from the use of this method are: a good sanitization of the barrel, a positive impact on the organoleptic characteristics of the wine and the ability to regenerate and reuse a barrel, with a positive effect on sustainability.
\end{abstract}

\section{Introduction}

In wine industry, the use of oak barrels is essential for aging and obtain a high quality wine. Extraction of oak wood compounds during barrel aging is of great importance since wine acquires complex aroma as well as increases its mouthfeel [1,2]. Moreover the maturation in oak barrels due to the slow diffusion of oxygen through barrel walls, promotes beneficial oxidation reactions which modify wine structure and colour $[3,4]$.

It is an expensive practice so barrels are reused several years, this aspect is critical since it increases the risk of wine spoilage, in particular the contamination from Brettanomyces bruxellensis. This yeast is commonly detected in used barrels and its development causes severe sensory consequences and influences the final quality of wine. This is due to the production of phenolic compounds, especially ethylphenols (4-ethylphenol and 4-ethylguaiacol) which are described as plastic, spicy, animal, horse sweat; their perception threshold is usually set at $620 \mu \mathrm{g} / \mathrm{L}[5,6]$ in red wines, even if the real identification varies among different wines depending on different factors such as ethanol and polyphenols content [7].

Together to Brettanomyces also some lactic acid bacteria and acetic acid bacteria represent a risk for wine during maturation both for their ability to produce metabolites that alter the organoleptic structure of wine $[8,9]$ and their possibility to produce biogenic amines which represent a risk for human health [10].

Therefore, it is clear that a good sanitization of barrels is a crucial phase in the production of consistently high quality wines. Different methods have already been

${ }^{a}$ Corresponding author: emilia.garciamoruno@

entecra.it proposed to sanitize the barrels: UV technology [11], microwave [12], ozone treatments [13] and others.

The dry ice blasting is an innovative technique of cleaning that uses dry ice granules $\left(\mathrm{CO}_{2}\right)$ which are sprayed using high pressure on a surface to remove contaminants and clean it. The granules of dry ice sublimate in gas during the impact, leaving no residues which could damage the equipment. It only eliminates the material to be removed without creating waste to be disposed. The dry ice blasting is already used as a method of cleaning in the food industry, it may be applied to clean food containers, tanks, conveyor food, food molds (wafers, chocolates, cakes, etc.), metal strips for ovens (cookies, crackers), food packaging machine, etc. and it is possible to extend its use in the wine industry.

The purpose of this study was to evaluate the effectiveness of blasting with dry ice to treat the barrels used for aging wine. First of all it was evaluated its efficacy on the reduction of the microbial growth. Subsequently it was evaluated its effect on the quality of wine by sensory analysis. In this step, a wine aged in a dry ice blasted barrique was compared with a wine aged in a barrique treated with sulfur dioxide, a common practice for the hygiene of the barrels. Data demonstrated that the dry-ice treatment represents an alternative method to the use of sulfur dioxide, reducing health risks during washing of barrels.

\section{Materials and methods}

\subsection{Dry ice-blasting treatment}

The dry ice-blasting treatment was performed using Microblast $\mathrm{CO}_{2} \mathrm{MB}$ MONO (MEC s.r.l., Caltignaga, Italy) (Fig. 1). It has the following characteristics: supersonic nozzle $(40 \times 3 \mathrm{~mm}), 7-7.5$ bar operating pressure, dry ice capacity of $40 \mathrm{~kg}$ and treatment duration of $5 \mathrm{~s} \times \mathrm{dm}^{2}$. 


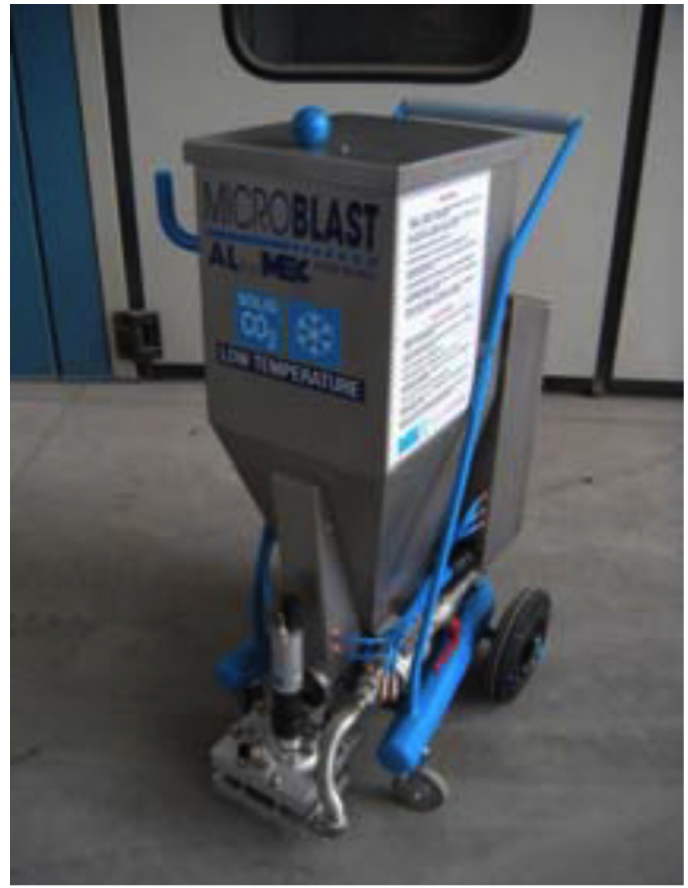

Figure 1. Dry-ice blaster used in all the assays made in this study.

\subsection{Microbiological analysis}

\subsubsection{Laboratory model: $1 \mathrm{dm}^{2}$ piece of barrel wood}

For the preparation of contaminated red wine, Brettanomyces bruxellensis ISE371 belonging to the CRA-ENO collection was grown in YEPG broth and then inoculated in the wine at $1 \times 10^{6}$ cell $/ \mathrm{mL}$.

Lactobacillus brevis ISE5033 was grown in MRS broth and inoculated in the wine at $2 \times 10^{6} \mathrm{cell} / \mathrm{mL}$.

A laboratory model was created as follows: the staves of three barriques were cut into pieces of $1 \mathrm{dm}^{2}$ of surface area. These pieces were taken for the lateral side of the barriques and from the staves.

The pieces of staves were introduced into tanks containing the contaminated wine and they were stored at room temperature for 5 days. Three samples were introduced into wine containing Brettanomyces and three samples were immerged in wine containing $L$. brevis.

\subsubsection{Microbial counts}

Microbial counts were determined using contact plates. Plates were made after incubation in the spoiled wine, subsequently all the models were dry ice blasted and again plated in order to evaluate the microbial load abatement. For the yeast count, Rose-Bengal Chloramfenicol agar (VWR, Milan, Italy) was used. For the total bacterial count, TSA plates were used (VWR). Plates were incubated at $25^{\circ} \mathrm{C}$ for 10 days.

\subsection{Sensory evaluation}

\subsubsection{Ageing in $225 \mathrm{~L}$ barriques}

In order to simulate real cellar conditions and to investigate the sensory impact of the dry ice-blasting treatment on wine, an assay was performed on $225 \mathrm{~L}$ barrels. Two barriques originating from the same manufacturer which had been used for 4 years, were subjected to different treatments: one was cryosandblasted as previously described (indicated as $\mathrm{R}$ ); one was treated with an $\mathrm{SO}_{2}$ solution ( $500 \mathrm{~g} \mathrm{~K}_{2} \mathrm{~S}_{2} \mathrm{O}_{5}$ in $225 \mathrm{~L}$ ), which remained in the barrique for 1 day and it was then emptied (indicated as $\mathrm{S}$ ).

After the treatment, the barrels were filled up with Barbera wine. The wine was aged for 6 months at $15^{\circ} \mathrm{C}$. The wine aged in the dry ice blasted barrique was designated wine R; the wine aged in the barrique treated with sulfur dioxide was designated as wine $\mathrm{S}$.

The $\mathrm{SO}_{2}$ content in wine was checked monthly and maintained at $20 \mathrm{mg} / \mathrm{L}$.

After ageing, both wines were subjected to sensory analysis to evaluate the organoleptic differences between the two samples.

\subsubsection{Sensory analysis}

All sessions were conducted at the Centro di Ricerca per l'Enologia (CRA-ENO). The panel was composed of 14-18 trained assessors (researchers and technicians at the CRA-ENO). ISO (3591-1977) approved glasses and an ISO (8589-2007) tasting room were employed for all of the sensory sessions. Each sample $(30 \mathrm{~mL})$ was coded by three random digits and covered with a Petri dish.

The wine sensory profiles were determined following the procedure derived from the ISO standards (110351994) and described in Cravero et al. [14]: the descriptors were chosen from a predefined odour list [15] integrated with colour and flavour (taste and mouth-feel sensation) descriptors.

For the wines aged for 6 months, the intensity of the chosen descriptors was measured on a structured scale ranging from 0 to $80 \mathrm{~mm}$.

\subsection{Statistical analysis}

Sensory data (sensory profiles) were statistically analysed: one-way ANOVA (treatment effect, assessor effect) was made using SPSS (SPSS 15.0 for Windows 2004; SPSS, Chicago, IL, USA).

\section{Results and discussion}

\subsection{Microbiological control}

A laboratory model was constructed dividing the wood of three barrels into pieces of $1 \mathrm{dm}^{2}$ of surface area. These wood models were kept in wine, artificially contaminated with Brettanomyces and Lactobacillus brevis, for 5 days. At the end of this experiment, the models were analysed with contact plates. Before the treatment, the surfaces of all the Rose-Bengal plates, selective for yeasts, were completely covered by colonies resulting in them being uncountable $\left(>10,000 \mathrm{CFU} / \mathrm{dm}^{2}\right)$. After dry ice blasting, the number of colonies was drastically reduced with a maximum of $200 \mathrm{CFU} / \mathrm{dm}^{2}$. The yeast counts made before and after the dry ice-blasting treatment are reported in Table 1. The plates selective for bacteria gave similar results, as reported in Table 2 . Therefore, this treatment allowed an abatement of $97.8-100 \%$ of the microbial load. 
Table 1. Yeast population from contact plates in laboratory model $\left(\mathrm{CFU} 100 \mathrm{~cm}^{2}\right.$ ) before and after dry-ice blasting treatment.

\begin{tabular}{lccc}
\hline Sample & $\begin{array}{c}\text { Before } \\
\text { treatment }\end{array}$ & $\begin{array}{c}\text { After } \\
\text { treatment }\end{array}$ & Abatement \% \\
\hline $\begin{array}{l}\text { (barrique 1, } \\
\text { lateral side) }\end{array}$ & $>10000$ & 0 & $100.00 \%$ \\
$\begin{array}{l}\text { (barrique 1, } \\
\text { lateral side B) }\end{array}$ & $>10000$ & 0 & $100.00 \%$ \\
$\begin{array}{l}\text { (barrique 2, } \\
\text { lateral side A) }\end{array}$ & $>10000$ & 25 & $99.75 \%$ \\
$\begin{array}{l}\text { (barrique 2, } \\
\text { lateral side B) }\end{array}$ & $>10000$ & 21 & $99.79 \%$ \\
$\begin{array}{l}\text { (barrique 3, } \\
\text { lateral side A) } \\
\text { (barrique 3, }\end{array}$ & $>10000$ & 30 & $99.70 \%$ \\
$\begin{array}{l}\text { lateral side B) } \\
\text { (barrique 1, }\end{array}$ & $>10000$ & 38 & $99.62 \%$ \\
stave A) & & 105 & $98.95 \%$ \\
(barrique 1, & $>10000$ & 42 & $99.58 \%$ \\
stave B) \\
(barrique 2, \\
stave A) \\
$\begin{array}{l}\text { (barrique 2, } \\
\text { stave B) } \\
\text { (barrique 3, } \\
\text { stave A) } \\
\text { (barrique 3, } \\
\text { stave B) }\end{array}$ & $>10000$ & 68 & $99.32 \%$ \\
\hline & $>10000$ & 114 & $98.86 \%$ \\
\hline
\end{tabular}

\subsection{Sensory analysis}

In order to study also the impact of this technique on the sensory aspects, and to simulate real conditions, a third assay was performed using $225 \mathrm{~L}$ barriques which had been used for 4 years.

The barriques were subjected to two different treatments. One of them was treated with sulfur dioxide and the second was dry ice blasted as described in Sect. 2. Fig. 2 shows the effect of dry-ice blasting on the wood, and how

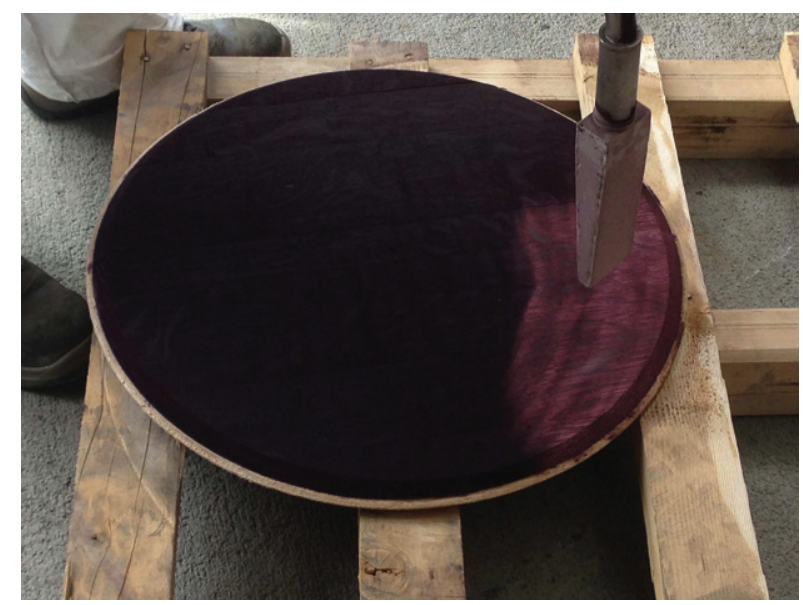

Figure 2. Flat side of the barrique during the dry-ice blasting.
Table 2. Bacteria population from contact plates in laboratory model (CFU $\left.100 \mathrm{~cm}^{2}\right)$ before and after dry-ice blasting treatment.

\begin{tabular}{lccc}
\hline Sample & $\begin{array}{c}\text { Before } \\
\text { treatment }\end{array}$ & $\begin{array}{c}\text { After } \\
\text { treatment }\end{array}$ & Abatement \% \\
\hline $\begin{array}{l}\text { (barrique 1, } \\
\text { lateral side) }\end{array}$ & $>10000$ & 6 & $>99.94 \%$ \\
$\begin{array}{l}\text { (barrique 1, } \\
\text { lateral side B) } \\
\text { (barrique 2, }\end{array}$ & $>10000$ & 6 & $>99.94 \%$ \\
$\begin{array}{l}\text { lateral side A) } \\
\text { (barrique 2, }\end{array}$ & $>10000$ & 20 & $>99.80 \%$ \\
$\begin{array}{l}\text { lateral side B) } \\
\text { (barrique 3, }\end{array}$ & $>10000$ & 0 & $>99.80 \%$ \\
$\begin{array}{l}\text { lateral side A) } \\
\text { (barrique 3, }\end{array}$ & $>10000$ & 0 & $100.00 \%$ \\
$\begin{array}{l}\text { lateral side B) } \\
\text { (barrique 1, } \\
\text { stave A) } \\
\text { (barrique 1, }\end{array}$ & $>10000$ & 0 & $100.00 \%$ \\
$\begin{array}{l}\text { stave B) } \\
\text { (barrique 2, } \\
\text { stave A) } \\
\text { (barrique 2, } \\
\text { stave B) } \\
\text { (barrique 3, } \\
\text { stave A) } \\
\text { (barrique 3, } \\
\text { stave B) }\end{array}$ & $>10000$ & 0 & $100.00 \%$ \\
\hline & $>10000000000000 \%$ & $100.00 \%$ \\
\hline
\end{tabular}

this treatment can remove the debris and eliminates the first mm of wood surface.

After the treatments they were filled up with the same Barbera wine and aged for 6 months.

The sensory profiles of both wines were defined. As shown in Fig. 3, the samples have a similar ruby red colour intensity and violet highlights, wine $\mathrm{R}$ showed a more complex aroma, characterized by a higher intensity of oak wood/boisé (statistically different) and vanilla. Moreover, wine $\mathrm{R}$ resulted in a slightly greater spicy note, along with a slightly higher intensity of cherry and jam notes. Regarding the taste, no significant differences were observed, but wine $\mathrm{R}$ resulted in being less bitter with a slightly higher intensity for structure, softness, taste-olfactory persistence and taste balance than wine $\mathrm{S}$.

These results demonstrate that this treatment allows to have an excellent reduction of microbial loads. Moreover the blasting operated by dry-ice, rejuvenates the wood allowing the extraction of further aromatic compounds with a positive impact on wine sensory profile, which resulted to have increased notes related to the aging in barrels.

\section{Conclusion}

The current trend in the wine industry is trying to replace the sulfur dioxide in wine-making, to this purpose research 


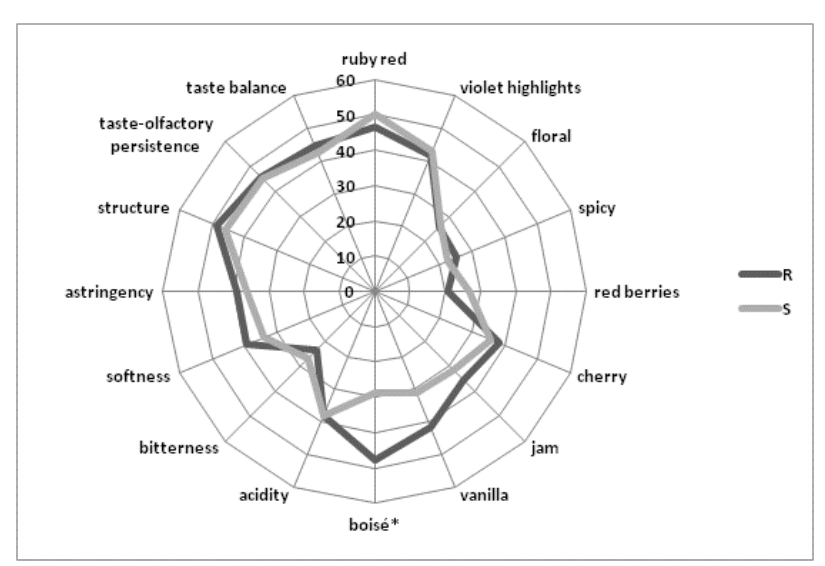

Figure 3. Comparison of the sensory profiles of the two wines $\mathrm{R}$ and $\mathrm{S}$ after 6 months of ageing showing the statistically significant differences $(*)$ (one-way ANOVA).

is moving to find alternative methods to its use in order to reduce the content of sulfites in wine.

In this work we studied the treatment of barrels with dry ice blasting from a microbiological and sensorial point of view. The carbon dioxide $\left(\mathrm{CO}_{2}\right)$ used in the blasting with dry ice is equal to that used in the food industry; it is an odorless, non-toxic chemical used in drink industry as an additive, this makes the technique ecological and with low environmental impact.

The data showed that the blasting with dry ice can be a valid alternative to sulfur dioxide for the treatment of used barrels. It confers the same effectiveness in reducing microbial loads and it offers the advantage that the wine aged in barrels dry ice blasted improves its organoleptic profile increasing aromatic notes of vanilla and boisé respect to a not dry-ice treated barrique.

\section{References}

[1] T. Garde-Cerdán, C. Lorenzo, G.L. Alonso, M.R. Salinas, Food Chem, 119, 823-828 (2010).

[2] C. Lorenzo, F. Pardo, A. Zalacain, G.L. Alonso, M.R. Salinas, Journal of food composition and analysis, 21, 54-61 (2008).

[3] V. Atanasova, H.T. Fulcrand, V. Cheynier, M. Moutounet. Analytica Chimica Acta, 458(1), 15-27 (2002).

[4] V. Cheynier, Proceedings of the Australian Society of Viticulture and Oenology Seminar, October 2002, (ASVO, Adelaide. 2002).

[5] P. Chatonnet, D. Dubourdie, J. Boidron, M. Pons, Journal of the Science of Food and Agriculture, 60 (2), 165-178 (1992)

[6] R. Suarez, J.A. Suarez-Lepe, A. Morata, F. Calderon, Food Chem, 102, 10-21 (2007)

[7] M. Petrozziello, A. Asproudi, M. Guaita, D. Borsa, S. Motta, L. Panero, A. Bosso, Food Chem, 149, 197-202 (2014)

[8] G.S. Drysdale, G.H. Fleet, Am J Enol Vitic, 39, 143-154 (1988)

[9] A. Costantini, E. Garcia-Moruno, M.V. MorenoArribas, Chapter 2 In Wine Chemistry and Biochemistry (Springer, New York, 2009)

[10] A. Costantini, M. Cersosimo, V. Del Prete, E. GarciaMoruno, J Food Prot, 69, 391-396 (2006)

[11] R. Guzzon, G. Widmann, M. Malacarne, T. Nardin, G. Nicolini, R. Larcher.Eur Food Res Technol 233, 285-291 (2011)

[12] L. González-Arenzana, P. Santamaría, R. López, P. Garijo, A.R. Gutiérrez, T. Garde-Cerdán, I. LópezAlfaro. Food Control 30, 536-539 (2013)

[13] R. Guzzon, T. Nardin, O. Micheletti, G. Nicolini, R. Larcher. Australian Journal of Grape and Wine Research 19, 180-188 (2013)

[14] MC Cravero, F. Bonello, C. Tsolakis, F. Piano, D. Borsa, It J Food Sci 24, 384-387 (2012)

[15] J. X. Guinard, A. C. Noble, Sc Alim 6, 657-662 (1986) 